\title{
Traditional and Online Media: Relationship between Media Preference, Credibility Perceptions, Predispositions, and European Identity
}

\author{
Waqas Ejaz \\ ORCID: 0000-0002-2492-4115 \\ NATIONAL UNIVERSITY OF SCIENCE AND TECHNOLOGY, \\ ISLAMABAD, PAKISTAN
}

\begin{abstract}
The present study investigates the relationship between people's preference of either traditional or online media for news consumption, credibility evaluation of media and their sense of European identity. In order to do so, the study draws on the Social Identity Theory and the findings of social psychologists which situate European identity a concept that corresponds to an individuals' subjective assignment to a collective and their affective and evaluative attachment to it. The analysis based on Eurobarometer survey data reveals that preferences of both online and traditional media for political news positively affects European identity. However, such an effect is dependent on people's pre-existing attitudes towards the EU and if they perceive the media to be neutral and credible.
\end{abstract}

KEYWORDS: European identity, news media selection, media credibility, political predispositions.

\section{INTRODUCTION}

In the 2010s, the European Union (EU) faced several difficult challenges, including the Eurozone's financial crisis, Britain's decision to leave the EU (Brexit), and the refugee crisis. In addition to these problems, the rise of populism across the EU could throw Europe into its next major existential crisis (Der Spiegel, 2018). Hence, the EU is at crossroads leading to the future (Mourao et al., 2015), and observers even believe that the EU is "doomed" (Lutz \& Striessnig, 2016, p. 305). These developments do not just indicate a lack of Europeans' political support for the EU but also highlights the "prevalence of national identity over European and the emergence of nationalist and anti-EU feelings among citizens" (Triga \& Vadratsikas, 2017, p. 4). There are numerous antecedents 
of people identifying less with the EU and developing Eurosceptic attitudes. Previous studies have argued about the EU's transformation into a "supranational regime with far-reaching competences" (Fuchs, 2011, p. 27), its reputation as a major threat to national symbols (McLaren, 2006), the costs and benefits of EU membership (Eichenberg \& Dalton, 2007; Gabel, 1998), the predominance of national identity concerns (Carey, 2002), as well as other factors, which can negatively impact on citizen's attitudes towards the EU, including their European identity.

Without discounting the relevance of past explanations and research, the present study argues the importance of news and information provided by traditional, i.e., TV, radio, newspaper, and online media, i.e., websites and social network platforms, in the formation and change of public opinion towards the EU (de Vreese \& Boomgaarden, 2006). Accordingly, the current study stresses the importance of media use for two reasons. First, the news and information disseminated "through media becomes part of the cognitive shortcuts adopted by the citizens to understand reality, including the European actuality" (Conti \& Memoli, 2016, p. 1). Second, in the case of the EU, due to a lack of direct and first hand experiences, citizens depend heavily on the mass media to obtain information about political matters (Norris, 2000), and this dependence in turn affects their political opinion and attitudes towards the EU (Rittberger \& Maier, 2008).

Although a large body of research confirms that the exposure to traditional mass media influences political attitudes towards the EU, only a few studies have analyzed the potential of online news media to affect public support for the EU (see, for exceptions, Conti \& Memoli, 2016; Mourao et al., 2015), and even fewer have examined its impact on European identity (for an overview, see Borz et al., 2018). This research gap is particularly surprising considering that in 2018, $41 \%$ of people (an increase of $2 \%$ from the previous year) across Europe relied on the internet - websites and online social networks - as their primary means to obtain news about European political matters (European Commission, 2018). This significant use of online sources for political news demands further research to determine its relationship with people's sense of European identity in comparison with the use of traditional media, which is also one of the goals of this study.

Besides the effects of the news media on the public, another significant strand of communication science literature emphasizes the central role of media credibility (Ladd, 2011). According to scholars, media credibility is a theoretical construct that includes but is not limited to the audience's trust in media and their perception of its objectivity (Kohring \& Matthes, 2007; Meyer, 1988). Previous studies have not only found a positive and modest association between media use and its credibility (Kiousis, 2001; Tsfati \& Cappella, 2003) but also shown that source credibility serves as an important moderator of media effects (Ladd, 2011). Thus, research on this subject warrants the inclusion of media credibility 
when assessing the effects of media use on its consumers. In the case of the EU, though ample evidence has been provided elucidating the effects of news on public opinion, there is still a lack of literature that examines simultaneously the interplay between media credibility, news, and public perception of the EU. This study intends to fill this gap.

In addition to examining the aforementioned relationships, the study further adds citizens' political predispositions to the model. The rationale to do so stems from recent empirical evidence suggesting that people's selection of certain media sources in the present-day news environment is driven by their previously held beliefs and expectations (Ceron \& Memoli, 2015; Newman and Nisbet et al., 2018). Thus, individual values and dispositions trigger cognitive media selection, and together both either reinforce or dampen the effects of news on political attitudes (Stroud, 2008).

Hence, in light of the aforementioned arguments, the study postulates that the four main concepts - the selection of certain media for news consumption, credibility perceptions of media, political predispositions, and sense of European identity - are interrelated. Therefore, this study examines the association amongst these concepts while investigating the interplay between the subjective evaluation of media credibility, traditional and online news preference, and European identity, together with examining the variation in this moderation in the presence of certain political predispositions.

In doing so, the following section first conceptualizes European identity and explains the theoretical considerations concerning the effects of traditional and online news media usage on political attitudes, particularly on people's sense of European identity. Afterward, the paper includes the significance of political predispositions and their association with news, credibility, and sense of identity. Then, the paper presents methods and the results sections. Finally, it concludes by discussing the key findings and limitations of the study.

\section{THEORY AND HYPOTHESES}

\section{EUROPEAN IDENTITY}

The idea of European identity corresponds to people's sense of "we-ness" (Keulman \& Koos, 2014), which signifies the psychological link between individuals and the communities to which they belong (Herrmann \& Brewer, 2004). The concept has been the subject of countless studies from various viewpoints. However, social identity theory (SIT) has been the seminal theoretical framework adopted in numerous empirical inquiries for investigating European identity (cf. Fuchs, 2011; Sojka, 2015) because it allows researchers to theorize the psychological 
process of both personal and collective identity formation while predicting its impact on socio-political behavior (Mols \& Haslam, 2008).

Polish-born British social psychologist Henri Tajfel (1978) introduced SIT, which was further developed by Tajfel and Turner (1979). Tajfel defines collective identity as "that part of an individual's self-concept which derives from his knowledge of his membership of a social group together with the value and emotional significance attached to that membership" (Tajfel 1978, p. 63).

According to this definition, European identity is a multi-dimensional concept that has at least three attitudinal dimensions: cognitive, evaluative, and affective (Kaina \& Karolewski, 2013).

The cognitive dimension implies an individual's knowledge and self-assignment to social groups and communities (Tajfel, 1981, p. 229). This knowledge emerges when an individual perceives that they have traits that are shared with other members of the group (Fuchs \& Schlenker, 2006). The evaluative dimension indicates the affirmations of these similarities and the positive or negative evaluation of these similarities, which allow the demarcation between the in-group and out-group (Fuchs, 2011). Thus, the evaluative component of collective identities involves a process of social comparisons between different collectives through the evaluation of the perceived similarities among them, which consequently determines in - and out-group memberships (Kaina \& Karolewski, 2013). Finally, the affective dimension denotes an individual's emotional attachment and feeling of belonging within a collective (Schäfer \& Weber, 2014).

In an effort to integrate the research on European identity and SIT, Dieter Fuchs (2011) proposes a framework presented in Table 1, according to which he distinguishes between the cognitive and affective/evaluative dimensions of SIT on two levels of identification, where he considers level 1 to be relatively more important. The first level deals with the cognitive and affective dimensions, and second deals with cognitive and evaluative dimensions of SIT.

Table 1. Dimensions of collective European identity

\begin{tabular}{|c|c|c|}
\hline & Cognition & Affective/Evaluation \\
\hline Level 1 & Subjective assignment to Europe/EU & $\begin{array}{l}\text { Affective attachment to the EU/Europe } \\
\text { We-feeling/feeling of belonging together }\end{array}$ \\
\hline Level 2 & $\begin{array}{l}\text { Subjective assumption of shared } \\
\text { similarities within the EU/Europe }\end{array}$ & Positive evaluation of assumed similarities \\
\hline
\end{tabular}

According to this adaptation, European identity is conceptualized as a multi-dimensional and integrated identification process. At the first level, individuals self-assign themselves to Europe/EU (cognition) and also feel attached to it (affection), while at the second level, they perceive similarities between other members 
within Europe/EU (cognition) and positively evaluate these similarities (evaluative). Moreover, Fuchs' (2011) model places emphasis not only on who identifies but also what this identification means and how is it evaluated in comparison to others (Sojka, 2015). Following his adaptation and argument regarding importance of the first level, the present study examines the two dimensions of SIT: cognitive, which refers to identification as European/citizen of the EU, and affective development, which denotes identification with Europe/EU (Cram, 2010; Fuchs 2011; Sojka, 2015).

\section{TRADITIONAL AND DIGITAL NEWS MEDIA, AND EUROPEAN IDENTITY}

The research on media use demonstrates that the use of online media for consuming news is consistently increasing across countries (Newman and Fletcher et al., 2018; Shearer \& Gottfried, 2017, including the EU (European Commission, 2018), which signifies the change in people's media preferences regarding news consumption. Similarly, recently released Digital News Report also indicates that people opt for multiple sources even amongst traditional and online media when it comes to consuming news (Newman and Fletcher et al., 2020). However, the proportions of people interacting and selecting traditional or online media vary across countries (Newman and Fletcher et al., 2020), signifying the differential preferences towards each media. Owing to these usage patterns and peculiarities of each news source, one can argue that the usage of one affects users' political opinions and attitudes quite differently than the other.

This notion of differential effects regarding traditional and online news media is also supported by research, which shows that citizens' usage and preference for different media outlets is related to their varying levels of interest in politics, political trust, and voting behavior (Avery 2009; Bailard 2012; Meeds 2015; van Spanje \& de Vreese, 2014). By contrast, the theory of intermedia agenda-setting and the dominance of legacy media dictate that media agendas tend to be highly homogeneous and reciprocal (Curran, 2012; Vargo \& Guo, 2017). This implies that the intrinsic differences between online, especially websites, and traditional media tend not to matter especially, when the legacy media still matters (Langer \& Gruber, 2020), and the content between the two essentially remains the same. However, the influence of legacy media may not be as strong on social network sites where user-generated content defines the contours and content of legacy media's landscape (Ismail et al., 2019, p. 169). But despite the contrasting arguments, in the case of the current study where online media means both websites and social networking sites, it is still relevant to assume that preference of either traditional or online media is varyingly associated with the specific EU related attitudes.

Accordingly, looking at how traditional media covers the EU, studies (e.g., Alarcón, 2010; Azrout et al., 2012) suggest that it tends to promote a negative image 
of the EU; whereas, there are investigations that contradict such findings (see, for example, Conti \& Memoli, 2016; de Vreese \& Boomgaarden, 2016). Usually, such mixed findings are a result of the varying focus on either the country (e.g., the UK where there is a prevalence of Euroscepticism) or selection of specific media (e.g., right-wing media that often takes anti-EU stance). However, despite the variance across countries (Nardis, 2015) and media, the literature tends to concur that traditional media promotes a positive image of the EU (for an overview, see Triga \& Vadratsikas, 2017). Additionally, research shows that positive coverage of the EU leads citizens to develop pro-EU attitudes (Conti \& Memoli, 2016) and since a citizen's sense of European identity corresponds to his pro-EU attitude (Gvozden 2008), the study presents the following hypothesis:

H1: The preference of traditional media for political news consumption is positively associated with European identity.

However, concerning online news consumption, the literature has found varying effects of its usage on citizens' political attitudes (Kaufhold et al., 2010; Mourao et al., 2015). but scholars still lack consensus in determining the nature of those effects (Rothmund \& Otto 2015). This ambiguity arises from the contradictory results of a variety of studies based on, for example, the design of the study (Boulianne 2015).

In the context of research concerning online news and political attitudes toward the EU, which is scarce, the few studies that have examined the topic have documented a negative bias regarding EU news in online media (Michailidou et al., 2014). Similarly, de Wilde et al. (2013) conclude that online media acts as a platform for people to be critical about the achievements and performance of the EU, consequently promoting and projecting anti-EU attitudes among citizens. Thus, in light of these empirical findings, the study assumes a negative association between online news media usage and European identity, and proposes the following hypothesis:

H2: The preference of online media for political news consumption is negatively associated with European identity.

\section{MEDIA CREDIBILITY AND POLITICAL PREDISPOSITIONS}

Research has already established that media use and exposure affect audiences' opinions, attitudes, and behaviors in various circumstances (de Vreese \& Boomgaarden, 2016; Diehl, Weeks, \& Zúñiga, 2015). However, scholars have recently shifted from merely detecting media effects to also examining the role of contextual factors that influence the impact of media effects (Tsfati \& Ariely, 
2014). The reason for this shift is the growing evidence that the effects of media can be "enhanced, diminished, or even blocked through the influence of some factors, suggestively called moderators" (Buturoiu \& Corbu, 2015, p. 157). Accordingly, among the moderators, people's assessment of media credibility is a highly consequential factor that affects the ability of media to influence citizens' trust in democracy (Tsfati \& Cohen, 2005), political participation, and partisan voting choice (Ladd, 2011). Moreover, a lack of media credibility prompts citizens to seek alternative news sources (Tsfati \& Ariely, 2014). Hence, one can infer that the credibility of media not only shapes people's selection of media but also moderates their political attitudes.

Here, it is necessary to mention that there is a paucity in literature that concerns investigating the relationship of media preference for news consumption and perception of media credibility along with their interaction, specifically with people's sense of European identity. Therefore, the number of possible interactions and the scarcity of empirical research in this area make it difficult to predict the impact of credibility perception and the direction of its interactions (if any) along with news media selection on European identity. Given this gap, the study aims to find the answer to the following research questions:

RQ1. How do the subjective credibility perceptions of (a) traditional and (b) online media influence European identity?

RQ2. Do subjective credibility perceptions of (a) traditional and (b) online media moderate the relationship between the preference of traditional/online media for news consumption and European identity?

In addition to the credibility of media, research has shown that people's predispositions are also important in investigating the effects of media on political attitudes. The reason to consider predispositions as relevant is the fact that they cause people to select and consume specific media that align with their preconceived notions (Ceron \& Memoli, 2015). Consequently, the pre-existing beliefs prompt people to selectively expose themselves to a particular type of media and content, which in turn influence their opinion and attitude formation (Newman and Nisbet et al., 2018; Stroud, 2008).

The literature regarding the role of media in shaping public opinions related to the EU also argues for the importance of individual beliefs and views in predicting support for the EU (see, e.g., Curtis \& Nielsen, 2018). For example, Goodwin et al. (2018) conclude that media coverage of the EU consistent with British people's prior beliefs, particularly their political affiliations - Labour or Conservative - leads to stronger framing effects. In the same vein, in their recent study, Baccini et al. (2016) conclude that predispositions together with the primary consumption of news from online media sources have reinforcement 
effects on people's attitudes towards the EU. Further, concerning European identity, Bergbauer (2018) has found sufficient evidence suggesting that pre-existing opinions can also explain people's sense of European identity. But despite being a well-researched topic, no studies have explored the role of political predispositions in the relationship of news consumption via online and traditional media on European identity. Therefore, in light of the above discussion and to further the research on this topic, the present paper proposes the following hypothesis:

H3: For both (a) traditional and (b) online media, positive/negative political predispositions reinforce the direct and moderating effects of media on European identity.

Figure 1 provides an overview of the research questions and hypotheses of the present study.

Figure 1. A statistical presentation of the conceptual variable model.

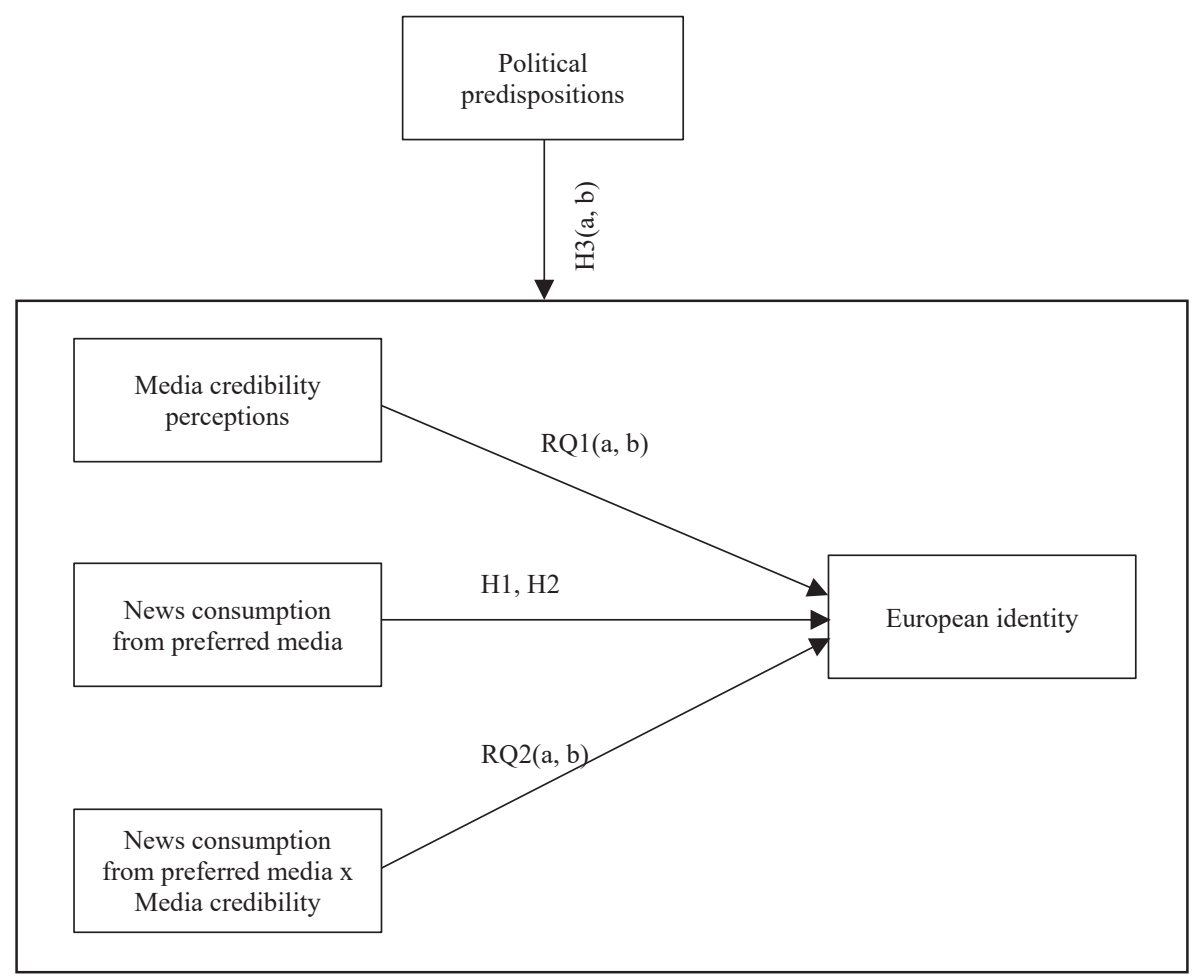

Source: Author 


\section{METHOD}

The study uses the data gathered through the EC's Standard Eurobarometer (EB) 88.3 survey from 2017 to validate the hypotheses and answer the research questions. This survey was selected because it offers recent data regarding European public opinion, and it contains all the relevant variables required for the present empirical analysis. In the following, the author explains the operationalization of those relevant variables.

\section{VARIABLES OF INTEREST}

Dependent Variable. The study uses two questions from the Eurobarometer survey to operationalize the dependent variable (European identity). First, the respondents were asked to answer the following question: "Please tell me how attached you feel to the European Union" using a scale from 1 (not attached at all) to 4 (very attached). The second question states, "Do you feel you are a citizen of the EU?", using a scale from 1 (no, definitely not), 2 (no, not really), 3 (yes, to some extent), and 4 (yes, definitely). The two items were highly correlated ( $\mathrm{r}=$ .67 ), and also had a suitable reliability score (Alpha $=.80$ ) and were therefore used to build an index to measure European identity. Based on the index, the mean level of European identity was about $2.74(\mathrm{~N}=27,920, S D=0.824)$, and in all countries, the mean value ranged between 2.3 and 3.2. However, there were some differences in the level of European identity between the countries. The negative outliers were Greece (2.3), United Kingdom (2.4), and the Czech Republic (2.4), while the positive exceptions were Luxembourg (3.2), Spain (3.1), and Germany (3.0).

Independent Variables. The independent variable concerning the preference of political news consumption from traditional or online media was operationalized through the following question: "Where do you get most of your news on European political matters? First? And then?" The possible answers were as follows: Television, the press, radio, websites, and online social networks. The author used the sum of two variables for each medium and then based on the mean values of television, press, and radio obtained one variable $(M=1.47, S D=$ 0.297) indicating the preference of news consumption through traditional media. Similarly, the mean use of websites and online social networks yielded the second variable $(M=1.23 ; S D=0.322)$, which indicates online media usage for European political news consumption. Furthermore, the reliability (Alpha $=-.60)$ and correlation $(\mathrm{r}=-.23, \mathrm{p}<.000)$ between the two variables confirmed their independence from each other, and suitability for respective constructs.

To operationalize the subjective media credibility perceptions as the moderating variable, the author used two indicators: general trust in the media and assessment of the objectivity of the EU-related content. Regarding trust in the 
media, the respondents were asked to indicate whether they tend not to trust (1) or tend to trust (2) on each of the following media sources: Television, the press, radio, the internet and online social networks. The first three had a high correlation of trust (between $r=.53$ and $r=.61$ ), and an appropriate score on the reliability scale $(\mathrm{Alpha}=0.81)$. These three were, therefore, computed as a single variable $(M=1.55 ; S D=0.35)$ reflecting trust in traditional media on a scale from 1 to 2 . Similarly, the correlation $(r=.60)$ and reliability $($ Alpha $=0.74)$ between trust in the internet and social networks prompted the author to build an index and transform both variables into a single variable $(M=1.33$; $S D=0.42)$ representing trust in online media.

The second indicator of subjective perceptions of media credibility was measured through the following question: "Do you think that the [national] television / radio / press / websites / online social network present(s) the EU too positively, objectively, or too negatively?" The answers were coded for each variable as 1 (too negatively or too positively) or 2 (objectively). The reason for assigning negative and positive perceptions toward the media to a single group is because such responses signify directional media bias (de Vreese \& Boomgaarden, 2006) and its evaluation as non-objective. However, the current study concerns itself only with the relationship of objective perceptions of media. Therefore, it makes sense to assign the directional bias of media and its objective perceptions to two different groups. Accordingly, the perception of objectivity among three traditional media types (television, radio, and press) was highly correlated (between $r=.61$ and $r=.67$ ), with a reliability score (Alpha $=.83$ ), and was thus suitable for index building. Similarly, the objectivity perception towards online media types (websites and online social networks) was also highly correlated ( $\mathrm{r}=.65$ ) with an appropriate reliability score (Alpha $=.79$ ), therefore, were used to measure objective perceptions toward online media.

Finally, the newly calculated individual variables of trust and objective perceptions for each traditional and online media were computed, resulting in two variables signifying media credibility assessment for traditional $(M=1.60 ; S D=$ $0.35)$ and online $(M=1.44 ; S D=0.37)$ media.

To determine the political predispositions of the respondents towards the EU, the author used the following question: "What does the EU mean to you personally?" The respondents could either say 'yes' or 'no' to sixteen different options, including (1) peace, (2) economic prosperity, (3) democracy, (4) social protection, (5) freedom to travel, study, and work anywhere in the EU, (6) cultural diversity, (7) stronger say in the world, (8) Euro, (9) unemployment, (10) bureaucracy, (11) waste of money, (12) loss of our cultural identity, (13) more crime, (14) not enough control at external borders, (15) other, and (16) don't know. In order to classify the predisposition as either positive or negative, the author conducted an exploratory factor analysis to ensure that the above items indeed 
belonged to either group. The result of the factor analysis classified the items in two components representing positive and negative predispositions towards the EU (see Table 2). Moreover, due to the ambivalence nature, and lower factor loadings of the Euro and social protection items, both were removed from the analysis. In the light of the factor analysis, the author computed the items into positive and negative groups and then calculated the difference between the two groups, which produced a single variable $(M=0.68 ; S D=2.10)$ with value ranging from -6 to 6 . Finally, to examine the direct and moderating effects of media on European identity among a group of people with either positive or negative predispositions, the author transformed the variable into a dichotomous variable $(M=0.34 ; S D=0.94)$, with the values from -6 to -1 showing negative perceptions (-1) towards the EU and values from 1 to 6 representing positive predispositions (1).

Table 2. Principal component matrix for 14 EU dispositional items based on EB 88.3

\begin{tabular}{l|c|c}
\hline & \multicolumn{2}{c}{ Components } \\
\cline { 2 - 3 } & Positive Predispositions & Negative Predispositions \\
\hline Cultural Diversity & 0.588 & \\
\hline Democracy & 0.570 & \\
\hline Peace & 0.545 & \\
\hline Travel/Study/Work Abroad & 0.540 & \\
\hline Stronger say in the world & 0.534 & \\
\hline Economic prosperity & 0.509 & \\
\hline Euro & 0.386 & 0.665 \\
\hline Social protection & 0.364 & 0.659 \\
\hline More crime & & 0.620 \\
\hline Waste of money & & 30.28 \\
\hline Not enough frontier control & 16.81 & 0.525 \\
\hline Loss of cultural identity & & 0.500 \\
\hline Bureaucracy & & 0.497 \\
\hline Unemployment & & 1.88 \\
\hline Initial eigenvalue & & \\
\hline Percentage explained variance & & \\
\hline Cumulative percentage & & \\
\hline & & \\
\hline
\end{tabular}

Source: Author

Control Variables. The study, in light of past research, and to make the analysis more robust, uses several control variables. Besides demographic control variables, that include age, gender and social class of respondents, the examination also controls for political knowledge about the EU, frequency of political discussion 
with friends, and current/future assessments of the European economy (Conti \& Memoli, 2016; Fuchs, 2011; Mourao et al., 2015).

\section{RESULTS}

Table 2 displays the results of the analysis based on multiple linear regression. Accordingly, hypothesis 1 proposes a positive impact of traditional media preference for news consumption on European identity. As shown in Table 3 (Model $1)$, choosing traditional media for political news consumption is significantly and positively associated with people's sense of European identity $(b=.08, p<.000)$.

RQ1a enquires about the impact of subjective credibility assessment of traditional media on European identity. The results in Table 2 show that the credibility perception of media in comparison to the preference of media appears to be an influential factor in explaining European identity. Further, its ability to predict European identity positively and significantly is consistent across all models.

The results regarding RQ2a show no interaction effect for traditional media in any of the given models. Simultaneously, this result also disproves H3a, which proposes the reinforcement of individual political predispositions on direct and moderating relationships between media variables and European identity. In contrast to that assumption, the result reveals that the direct relationship of independent variables do not align with the predispositions. Instead, the effects remain positive and are even strengthened among people with negative predispositions. Finally, the association of the control variables across all models are in line with the previous research on the subject such as people who belong to a higher social class tend to have a higher level of European identity (Sojka, 2015). Similarly, those who have high political knowledge about the EU and frequently engage in political discussion tend to have a higher European identity. Moreover, people who believe that the European economy is performing well and expect it do so, also tend to have a higher sense of European identity (Conti and Memoli, 2016).

Table 3. Regression analysis predicting preference of Traditional/Digital media on European identity

\begin{tabular}{l|c|c|c|c}
\hline \multicolumn{1}{l}{ Scale Items } & Model 1 & Model 2 & Model 3 & Model 4 \\
\hline $\mathrm{N}_{2}$ & 20112 & 20112 & 11361 & 5469 \\
\hline $\mathrm{R}$ & .20 & .20 & .10 & .14 \\
\hline Political discussion & $.10^{* * *}$ & $.10^{* * *}$ & $.16^{* * *}$ & .01 \\
\hline Knowledge about the EU & $.05^{* * *}$ & $.05^{* * *}$ & $.05^{* * *}$ & $.06^{* * *}$ \\
\hline
\end{tabular}




\begin{tabular}{l|c|c|c|c}
\hline Scale Items & Model 1 & Model 2 & Model 3 & Model 4 \\
\hline Social class & $.09^{* * *}$ & $.09^{* * *}$ & $.06^{* * *}$ & $.11^{* * *}$ \\
\hline Age & $-.06^{* * *}$ & $-.06^{* * *}$ & .00 & $-.05^{* * *}$ \\
\hline EU economic expectation & $.13^{* * *}$ & $.13^{* * *}$ & $.09^{* * *}$ & $.10^{* * *}$ \\
\hline EU economic situation & $.22^{* * *}$ & $.22^{* * *}$ & $.013^{* * *}$ & $.17^{\star * *}$ \\
\hline Traditional media selection & $.08^{* * *}$ & $.08^{* * *}$ & $.05^{* * *}$ & $.07^{* * *}$ \\
\hline Digital media selection & $.06^{* * *}$ & $.07^{* * *}$ & $.04^{* *}$ & $.08^{* * *}$ \\
\hline Traditional media credibility & $.14^{* * *}$ & $.14^{* * *}$ & $.07^{* * *}$ & $.14^{* * *}$ \\
\hline Digital media credibility & $.03^{* * *}$ & $.03^{* * *}$ & $.03^{* * *}$ & .02 \\
\hline $\begin{array}{l}\text { Traditional media selection } \\
\text { X Traditional media credibility }\end{array}$ & & -.00 & .00 & -.02 \\
\hline $\begin{array}{l}\text { Digital media selection } \\
\text { X Digital media credibility }\end{array}$ & & $-.02^{* *}$ & .00 & $-.03^{* *}$
\end{tabular}

Note: Model 1: Baseline model; Model 2: With interaction; Model 3: Positive predisposition;

Model 4: With negative predispositions; Standardized regression coefficients are reported, and the p-value significance varies: ${ }^{\star}<0.1$; $^{* *}<0.05 ;^{* * *}<0.01$ : Cell entries are standardized beta coefficients. DV: European identity. All variables are mean-centred

In $\mathrm{H} 2$, the author proposed that the preference of consuming political news through online media makes people more cynical towards the EU, which negatively impacts their sense of European identity. However, the results presented in Table 3 (Model 1) indicates that the opposite is true because the use of online media for political news consumption is positively associated with the European identity ( $b=.06, p<.001)$. Moreover, this positive relationship between the two variables was not only consistent but slightly increases in strength (in opposition to traditional media) whenever the interaction between variables is included in respective models.

In addition to the supposed effect of online news usage, RQ1b was concerned with the influence of media credibility perceptions on European identity. Accordingly, the results (Table 2) indicate that the credibility perception of online media had a positive significant relation with European identity across all models except in Model 4 which examines people with negative predispositions towards the EU. Unlike traditional media, the results do not show that the subjective assessment of online media credibility is better than selecting online media for news consumption in predicting people's sense of European identity. However, comparing the results for both media types, it appears that credibility perceptions of the traditional media is more consequential than those of online media, and this trend is consistent across all models.

As for the interaction effects (RQ2b), the results (Model 2) show that the perception of online media credibility significantly and negatively moderate the relationship between the preference of online media and people's sense of European identity $(b=-.02, p<.05)$. The presence of a significant interaction 
indicates that the effect of one independent variable on the dependent variable is different at different values of the other independent variable (Conti \& Memoli, 2016). Thus, in this case, it implies that European identity not only depends on a citizen's preference of online media for political news consumption but also on whether or not the citizen evaluates the online media to be trustworthy and objective.

In $\mathrm{H} 3 \mathrm{~b}$, it is proposed that political predispositions reinforce the direct and moderating relationships of online media on European identity. The result (Model 3) in this regard shows that positive predispositions neither reinforce the direct relationship of the independent variables on the dependent variable nor generate any interaction effects. However, negative predispositions moderately amplified both the direct relationship of online news consumption $(b=$ $.08, p<.000)$, and its interplay with media credibility perceptions on European identity $(b=-.03, p<.05)$.

\section{DISCUSSION}

The present study investigates (a) how the preference of traditional or online media for news consumption along with the perception of its credibility impact and interact with people's sense of European identity (b) and whether this influence becomes more pronounced when people hold distinctive predispositions toward the EU. The previous literature regarding the effects of media suggest that news related to European politics matters in general and is related to public attitudes toward the EU. However, to the best of the author's knowledge, no studies have explored the relationship between the preference of traditional or online news as well as the perception of its credibility and their interplay with European identity among contrarily predisposed people. The current study fills this gap, and in doing so, it not only identifies the positive association of news media selection with European identity but also shows the contingency of these relationships on the perception of media credibility and political predispositions.

The results in the previous section revealed that the preference of both traditional and online media for political news consumption is directly and positively associated with European identity. Hence, this study supports past research showing that the consumption of traditional media news makes people feel attached to the EU, and this is because it tends to cover the EU in a positive manner, thus leading to a positive effect (de Vreese \& Boomgaarden, 2016; Staehelin, 2016).

In the context of online media, the findings add to the growing body of literature (e.g., Mourao, et al., 2015) that differs from earlier studies, according to which the use of online media for political information adds to Euroscepticism (Conti 
\& Memoli, 2016; de Wilde at al. 2013). One reason for this difference is that such studies have investigated the impact of online media use on attitudes associated with functional aspects of the EU (Easton 1975), such as support for its policies and evaluation of its institutions, and these are relatively easy to change. Identity in general, and European identity in particular, is a quite stable and resilient feeling that acts as a buffer against Euroscepticism (Weßels, 2007).

Another reason for this positive effect can be explained by research on intermedia agenda-setting and legacy media literature, which shows traditional and online media entities are "homogenous", and the legacy media is still highly influential in driving online content (Harder et al., 2017, p. 276; Langer \& Gruber, 2020). This implies that if the traditional media choses to cover the EU positively, it is likely that similar content permeates the internet. Recent studies have shown that the traditional media in most member states (with the exception of the British and right-wing media) usually presents the EU positively (Bayley \& Williams, 2012; de Vreese \& Boomgaarden, 2016). Following intermedia agenda-setting logic, this means that such coverage infuses into online media, and as a result, consumption of both forms of media for news instil a sense of European identity in people.

In addition to news media preferences, the present study found that evaluating media as credible is an important determinant of European identity. This result supports previous findings emphasizing the positive role of media credibility on political attitudes (Ladd, 2011; Tsfati \& Ariely, 2014). Moreover, news consumption from online media and the subjective assessment of its credibility both negatively and significantly interact with European identity. This means that the strength and direction of the relationship between media selection and European identity are affected by subjective credibility perceptions of online media. The study found such interaction effects only when the respondents were either 'not at all' or only 'negatively' predisposed. As for the reinforcement effect, the results (Model 4) show the ability of negative predispositions to reinforce the interaction effects, which consequently weakens European identity.

The study has some limitations and caveats that should be considered in the interpretation of the results. Since, the present analysis aimed at investigating the relationships between various media variables and European identity at the macro-level, therefore, the analysis focuses on the entirety of EU28, instead of on individual countries. Hence, the results are only generalizable and applicable to that extent because previous studies have highlighted variations across countries when it comes to the effects of media on attitudes towards the EU (Nardis, 2015). Furthermore, although the results have explicitly shown that news consumption from different media sources is related to the people's sense of European identity, the models, however, cannot establish the causal direction with certainty in the highlighted relationships. Therefore, future studies on the 
topic should take the content of political news from distinctive types of media into consideration. Despite the limitations, this study contributes to the existing literature by showing how consuming news from both traditional and online media, along with the perception of their credibility and people's pre-existing attitudes towards the EU, are important predictors of European identity.

\section{REFERENCES}

Alarcón, A. (2010). Media representation of the European Union: Comparing newspaper coverage in France, Spain and the United Kingdom. International Journal of Communication, 4, 398-415.

Avery, J. M. (2009). Video-malaise of virtuous circle? The influence of the news media on political trust. The International Journal of Press/Politics, 14(4), 410-433.

Azrout, R., van Spanje, J., \& de Vreese, C. (2012). When news matters: Media effects on public support for European Union enlargement in 21 countries. Journal of Common Market Studies, 691-708.

Baccini, L., Sudulich, L., \& Wall, M. (2016). Internet effects in times of political crisis: Online newsgathering and attitudes toward the European Union. Public Opinion Quarterly, 80(2), 411-436.

Bailard, C. S. (2012). Testing the internet's effect on democratic satisfaction: A multi-methodological, cross-national approach. Journal of Information Technology \& Politics, 9(2), 185-204.

Bayley, P., \& Williams, G. (2012). European identity: What the media say (1st ed.). Oxford: Oxford University Press.

Bergbauer, S. (2018). Explaining European identity formation: Citizens' attachment from Maastricht Treaty to crisis. Cham: Springer Nature.

Borz, G., Brandenburg, H., \& Mendez, C. (2018). The impact of EU cohesion policy on European identity: Results from the Cohesify citizen survey. Retrieved May 9, 2019, from Cohesify: http://www.cohesify. eu/wp-content/uploads/2018/05/Cohesify-survey-report_-final1.pdf

Boulianne, S. (2015). Social media use and participation: a meta-analysis of current research. Information, Communication \& Society 18(5), 524-538.

Buturoiu, D. R., \& Corbu, N. (2015). Moderators of framing effects on political attitudes: Is source credibility worth onvestigating? Central European Political Studies Review, 17(2), 155-177.

Carey, S. (2002). Undivided loyalties: Is national identity an obstacle to European integration. European Union Politics, 3, 387-413.

Ceron, A., \& Memoli, V. (2015). Trust in government and media slant: A cross-sectional analysis of media effects in twenty-seven European countries. The International Journal of Press/Politics, 20(3), 339-359.

Conti, N., \& Memoli, V. (2016). Citizens, Europe and the media: Have new media made citizens more Eurosceptical? London, UK: Palgrave Macmillan.

Cram, L. (2010). Does the EU need a navel? Banal Europeanism, appreciated Europeanism and European integration. ECPR Fifth Pan-European Conference. Porto.

Curran, J. (2012). Reinterpreting the internet. In J. Curran, N. Fenton, \& D. Freedman, Misunderstanding the Internet (pp. 3-33). New York: Routledge. 
Curtis, K. A., \& Nielsen, J. H. (2018). Predispositions matter... But how? Ideology as a mediator of personality's effects on EU support in five countries. Political Psychology, 39(6), 1251-1270. https://doi. org/10.1111/pops.12546

de Vreese, C. H., \& Boomgaarden, H. G. (2006). Media effects on public opinion about the enlargement of the European Union. Journal of Common Market Studies, 44(2), 419-36.

de Vreese, C., \& Boomgaarden, H. (2016). Effects of news media coverage on public support for European integration. In W. Van Der Brug, \& C. de Vreese (Eds.), (Un)intended consequences of EU Parliamentary elections (pp. 237-254). Oxford: Oxford University Press.

de Wilde, P., Michailidou, A., \& Trenz, H.-J. (2013). Contesting Europe. Exploring Euroscepticism in online media (1st Edition ed.). Colchester: ECPR Press.

Der Spiegel. (2018, June 1). Italy sends a jolt through Europe. Retrieved from Der Spiegel: http://www.spiegel. de/international/europe/the-crisis-in-italy-threatens-to-become-a-european-tragedy-a-1210699.html

Diehl, T., Weeks, B., \& Zúñiga, H. G. (2015). Political persuasion on social media: Tracing direct and indirect effects of news use and social interaction. New Media \& Society, 18 (9), 1875-1895.

Easton 1975 - A reassessment of the concept of political support. British Journal of Political Science, $5,435-57$.

Eichenberg, R., \& Dalton, R. (2007). Post-Maastricht blues: The transformation of citizen support for European integration, 1973-2004. Acta Politica, 42(2), 128-152.

European Commission. (2018). Standard Eurobarometer 90 media use in the European Union. Brussels: European Union.

Fuchs, D. (2011). Cultural diversity, European identity and legitimacy of the EU: A theoretical framework. In D. Fuchs, \& H.-D. Klingemann (Eds.), Cultural Diversity, European Identity and Legitimacy of the EU (pp. 27-57). Cheltenham, UK: Edward Elgar Publishing Limited.

Fuchs, D., \& Schlenker, A. (2006, April 1). European identity and the legitimacy of the EU. Retrieved June 21, 2018, from Semantic scholar: shorturl.at/kmGIJ

Gabel, M. (1998). Public support for Europe: an empirical test of five theories. Journal of Politics, $60,333-354$.

Goodwin, M., Hix, S., \& Pickup, M. (2018). For and against Brexit: A survey experiment of the mpact of campaign effects on public attitudes toward EU membership. British Journal of Political Science, 1-15.

Gvozden, V. (2008). Some remarks on the relationship between European identity and the European Union. In K. Hanshew (Ed.), EU=Europe? Euroskepticism and European identity (pp. 9-18). München: Forost.

Harder, A. R., Sevenans, J., \& Van Aelst, P. (2017). Intermedia agenda setting in the social media age: How traditional players dominate the news agenda in election times. The International Journal of Press/Politics, 275-293.

Herrmann, R., \& Brewer, M. B. (2004). Identities and institutions: Becoming European in the EU. In R. K. Herrmann, T. Risse, \& M. B. Brewer (Eds.), Transnational identities: Becoming European in the $E U$ (pp. 1-22). Lanham, MD: Rowman \& Littlefield.

Ismail, A., Torosyan, G., \& Tully, M. (2019). Social media, legacy media and gatekeeping: the protest paradigm in news of Ferguson and Charlottesville. The Communication Review, 22(3), 169-195. 
Kaina, V., \& Karolewski, P. (2013, July 23). EU governance and European identity. Retrieved June 10, 2017, from Living Reviews: http://www.livingreviews.org/lreg-2013-1

Kaufhold, K., Valenzuela, S., \& De Zúñiga, G.H. (2010). Citizen journalism and democracy: How user-generated news use relates to political knowledge and participation. Journalism \& Mass Communication Quarterly, 87, 515-529.

Keulman, K. and Koós, A. (2014). European Identity: Its feasibility and desirability. Lanham: Lexington Books.

Kiousis, S. (2001). Public trust or mistrust? Perceptions of media credibility in the information age. Mass Communication \& Society, 4(4), 381-403.

Kohring, M., \& Matthes, J. (2007). Trust in news media development and validation of a multidimensional scale. Communication Research, 34(2), 231-252.

Ladd, J. (2011). The role of media distrust in partisan voting. Political Behavior 32(4), 567-585.

Langer, A., \& Gruber, J. (2020). Political agenda setting in the hybrid media system: Why legacy media still matter a great deal. The International Journal of Press/Politics (Early Online Publication).

Lutz, W., \& Striessnig, E. (2016, Jun 2). Demographic strengthening of European identity. Population and Development Review, 42(2), 305-311.

McLaren, L. M. (2006). Identity, interests, and attitudes to European integration. New York: Palgrave Macmillan.

Meeds, R. (2015). Changing roles of traditional and online media as trusted news sources in Qatar and their relationships with perceived important issues and interest in politics. Journal of Middle East Media, 11, 34-61.

Meyer, P. (1988). Defining and measuring credibility of newspapers: Developing an index. Journalism \& Mass Communication Quarterly, 65(3), 567-574.

Michailidou, A., Trenz, H.-J., \& de Wilde, P. (2014). The internet and European integration: Pro - and anti-EU debates in online news media. Berlin: Barbara Budrich.

Mols, F., \& Haslam, A. (2008). Understanding EU attitudes in multi-level governance contexts: A social identity perspective. West European Politics, 31(3), 442-463.

Mourao, R., Yoo, J., Giese, S., Araiza, J., Kilgo, D., \& Johnson, T. (2015). Online news, social media, and European Union attitudes: A multidimensional analysis. International Journal of Communication, 9, 3199-3222.

Nardis, Y. (2015). News, trust in the European Parliament, and EP election voting: Moderated-mediation model investigating voting in established and new member states. The International Journal of Press/Politics, 20(1), 45-66.

Newman, N., Fletcher, R., Kalogeropoulos, A., Levy, D., \& Nielsen, R. K. (2018). Digital news report 2018. Oxford: Reuters Institute for the Study of Journalism.

Newman, N., Fletcher, R., Schulz, A., And1, S., \& Nielsen, R. K. (2020, June 16). Reuters Institute digital news report 2020. Retrieved from University of Oxford: https://reutersinstitute.politics.ox.ac.uk/ sites/default/files/inline-files/DNR_2019_FINAL.pdf

Newman, T., Nisbet, E., \& Nisbet, M. (2018). Climate change, cultural cognition, and media effects: Worldviews drive news selectivity, biased processing, and polarized attitudes. Public Understanding of Science 27(8), 985-1002. 
Norris, P. (2000). A virtuous circle? The impact of political communications in post-industrial democracies. Cambridge: Cambridge University Press.

Rittberger, B., \& Maier, J. (2008). Shifting Europe's boundaries: mass media, public opinion and the enlargement of the EU. European Union Politics, 9(2), 243-267.

Rothmund, T., \& Otto, L. (2015). The changing role of media use in political participation. Journal of Media Psychology, 28(3), 97-99.

Schäfer, C., \& Weber, D. (2014). European identity in times of crisis. ECPR Graduate Student Conference in Innsbruck. Innsbruck.

Shearer, E., \& Gottfried, J. (2017, September 7). News use across social media platforms 2017. Retrieved from Pew Research Center: shorturl.at/mpvzI

Sojka, A. A. (2015). We, the new citizens of Europe: European identity in Central and Eastern European Member States of the European Union. Determinants, contents and consequences. Granada: Universidad de Granada. Retrieved from http://hdl.handle.net/10481/39863

Staehelin, K. P. (2016). Drivers of change? Media effects on the identity and utilitarian EU attitude dimensions. University of Amsterdam, Department of Communication Science. Amsterdam: University of Amsterdam.

Stroud, N. J. (2008). Media use and political predispositions: Revisiting the concept of selective exposure. Political Behavior, 30, 341-366.

Tajfel, H. (1978). Differentiation between social groups. Studies in the social psychology of intergroup relations. London: Academic Press.

Tajfel, H. (1981). Human groups and social categories: Studies in social psychology. Cambridge: Cambridge University Press.

Tajfel, H., \& Turner, J. (1979). An integrative theory of intergroup conflict. In J. A. Williams, \& S. Worchel (Eds.), The social psychology of intergroup relations (pp. 33-47). Belmont: Wadsworth.

Triga, V., \& Vadratsikas, K. (2017). The impact of media representations of the EU and its policies on European identity. Department of Communication and Internet Studies. Limassol: Department of Communication and Internet Studies.

Tsfati, Y., \& Ariely, G. (2014). Individual and contextual correlates of trust in media across 44 countries. Communication Research, 41(6), 760-782.

Tsfati, Y., \& Cappella, J. N. (2003). Do people watch what they do not trust? Exploring the association between news media skepticism and exposure. Communication Research, 30(5), 504-529.

Tsfati, Y., \& Cohen, J. (2005). Democratic consequences of hostile media perceptions: The case of Gaza settlers. Harvard International Journal of Press/Politics, 10, 28-51.

van Spanje, J., \& de Vreese, C. (2014). Europhile media and eurosceptic voting: Effects of news media coverage on eurosceptic voting in the 2009 European Parliamentary elections. Political Communication, 31(2), 325-354.

Vargo, C., \& Guo, L. (2017). Networks, big data, and intermedia agenda setting: An analysis of traditional, partisan, and emerging online U.S. news. Journalism and Mass Communication Quarterly, 94(4), 1031-1055.

Weßels, B. (2007). Discontent and European identity: Three types of euroscepticism. Acta Politica, $42,287-306$. 